\title{
Os espaços da Libras em contextos artístico-culturais e literários e a formação de tradutores e intérpretes de Libras-português
}

\author{
Neiva de Aquino Albres ${ }^{1}$ \\ Programa de Pós-graduação em Estudos da Tradução - PGET, Universidade Federal de Santa Catarina, \\ Florianópolis, SC, Brasil
}

Resumo: Procuramos investigar os diferentes espaçostempos educativos para a aprendizagem de performances artísticas em língua de sinais, como também os processos tradutórios e interpretativos. Este trabalho inscreve-se no campo teórico dos Estudos da Tradução e dos Estudos da Tradução de Língua de Sinais, em suas subáreas didática e formação. Para tanto, realizou-se uma pesquisa qualitativa, do tipo descritiva, com abordagem teórica dialógica (BAKHTIN, 2017). A pesquisa caracteriza-se como documental, fundamentada em dados primários. O estudo é desenvolvido com base nos cursos superiores de formação de Tradutores e intérpretes de Libras/Língua Portuguesa (TILSP) no Brasil entre os anos 2008 e 2019, a fim de realizar o levantamento de suas matrizes curriculares e extrair do conteúdo das disciplinas que são relacionados à arte e cultura, o que contribuiria para a atuação como TILSP na esfera artística. Os resultados apontam: o evidente crescimento do contexto artístico-cultural enquanto campo de trabalho em Florianópolis, absorvendo, principalmente, alunos egressos do curso.

Palavras-chave: Formação de Tradutores e Intérpretes de Libras/Língua Portuguesa (TILSP); Contextos Artístico-Culturais e Literários; Matrizes Curriculares; Cursos Superiores.

Title: Artistic-cultural and literary contexts in Brazil and the training of translators and interpreters of Libras-Portuguese

Abstract: We seek to investigate the different learning spaces for the learning of artistic performances in sign language, as well as the translational and interpretative processes. This work is part of the theoretical field of the Translation Studies and Sign Language Studies, in its didactic and training subareas. For this purpose, was made a qualitative research (descriptive type), with dialog theoretical approach. The research is characterized as a documentary type, based on primary data. The study is based on TILSP training courses in higher education in Brazil between the years 2008 and 2019, to survey their curriculum matrices and extract from the contents of the discipline what would be the art and culture, which would contribute to acting as TILSP in the artistic sphere. The results aim: the evident growth of the artistic-cultural context as a playing field in the in Florianópolis, absorbing, mainly, students graduating from the course.

Keywords: Training of Translators and Interpreters of Libras-Portuguese; Artistic-Cultural and Literary Contexts; Curriculum matrices; Higher Education.

\footnotetext{
${ }^{1}$ Doutora em Educação Especial (Universidade Federal de São Carlos - UFSCar), Pesquisadora e docente na Universidade Federal de Santa Catarina - UFSC. Orcid: https://orcid.org/0000-0003-1567-297X. E-mail: neiva.albres@ufsc.br.
} 


\section{Introdução}

As políticas linguísticas que preveem que os bens culturais sejam oferecidos, proferidos e veiculados em Língua Brasileira de Sinais, a Libras, têm crescido desde os anos 2000. Somando normativas, leis e decretos que garantem desde "promoção da acessibilidade" a fim de romper as barreiras construídas culturalmente, tanto físicas quanto atitudinais, para promover a "participação social da pessoa, bem como o gozo, a fruição e o exercício de seus direitos à acessibilidade, à liberdade de movimento e de expressão, à comunicação, ao acesso à informação, à compreensão" (BRASIL, 2000a), prioridade de atendimento (BRASIL, 2000b), como também espaços e os assentos às pessoas surdas para boa visualização da interpretação em Libras e da legendagem descritiva, previstos para "teatros, cinemas, auditórios, estádios, ginásios de esporte, locais de espetáculos, de conferências e similares" (BRASIL, 2004).

A Agência Nacional do Cinema (ANCINE) regulamenta a inclusão de recursos de acessibilidade auditiva e visual nas salas de cinema, objetivando a padronização do acesso audiovisual, envolvendo "tecnologia assistiva voltada à fruição dos recursos de legendagem, legendagem descritiva, audiodescrição e LIBRAS - Língua Brasileira de Sinais" (ANCINE, 2016, on-line).

A Lei Brasileira de Inclusão da Pessoa com Deficiência (Estatuto da Pessoa com Deficiência) - LBI (BRASIL, 2015), entre outras medidas, estabelece o direito à língua de sinais como mecanismo de acessibilidade, em diversas esferas, explicitando o "direito à cultura", acesso em; "I - a bens culturais em formato acessível; II - a programas de televisão, cinema, teatro e outras atividades culturais e desportivas em formato acessível; e III - a monumentos e locais de importância cultural e a espaços que ofereçam serviços ou eventos culturais e esportivos". (BRASIL, 2015, on-line). Assim, as políticas linguísticas apontam para o respeito à Libras como língua minoritária no Brasil.

Com base na legislação apontada, tem crescido a oferta desses tipos e trabalho enquanto a pouca formação existente para esses profissionais parece não aprofundar nesse tipo de atuação. Assim, esta pesquisa visa descrever e analisar a formação de Tradutores e intérpretes de Libras/Língua Portuguesa (TILSP) para atuação na esfera artístico-cultural. E tem como objetivos específicos: 1) Levantar os conteúdos das disciplinas dos cursos de graduação que abordam algum tema para formação para atuação na esfera artístico-cultural. 2) Mapear e comparar as diferentes oportunidades de formação em cursos de extensão (palestras, minicursos, oficinas) realizadas em Florianópolis, Santa Catarina.

\section{A esfera artístico-cultural e a interpretação para Libras: novos espaços para uma língua minoritária}

A profissão de intérpretes de língua de sinais ainda é jovem e começou a se desenvolver no Brasil no final dos anos 1990, formatando cursos superiores nos anos 2000. Até então, filhos de pais surdos ou outros membros da família interpretavam comunicações diversas, sem estar realmente consciente de que assumiram um papel de intérpretes (COKELY, 
2005). A interpretação não é um favor e sim um direito linguístico, o surdo torna-se um consumidor, e requer-se cada vez mais intérpretes qualificados para atuação em diferentes esferas da vida social (ROY; METZGER, 2014). Há particularidades envolvendo o trabalho com textos literários, artísticos e dramáticos (peças teatrais) (FOMIN, 2018).

Os contextos artístico-culturais desde o século passado foram descritos, em nível internacional, como espaços de atuação de TILSP (BAKER; SALDANHA, 1998; NAPIER; MCKEE; GOSWELL, 2006). No entanto, no Brasil, a presença da TILSP tem ganhado corpo a partir dos anos 2010 com políticas públicas de acessibilidade que são, no entanto, políticas linguísticas.

Uma primeira questão teórica se refere à especificação do que envolve a esfera artístico-cultural. Conforme o Parâmetro Curricular Nacional (PCN), compreenderia as diferentes formas artísticas, desde Artes Visuais, Dança, Música ou Teatro. Produções culturais podem envolver também a literatura, poesia e cinema (BRASIL, 1997). Sendo assim, a esfera artístico-cultural abrange uma gama de eventos. Neste texto, vamos empregá-la para se referir à atuação de TILSP em espaços de Arte e Cultura como: Museu de Arte (em que tem a intervenção de curadores e arte-educadores interpretada simultaneamente ou mesmo a tradução de vídeo institucional e da exposição com visitas guiadas e agendadas), atuação de TILSP na produção de vídeos em Libras sobre as exposições, que podem ficar em tablets alocados em salas ou em outro suporte, como também na tradução dos materiais a serem divulgados nos sites e páginas de web dos museus.

A afinidade entre arte e educação é estreita, relaciona-se ao contato com a literatura, por meio da tradução literária registrada em suporte material (vídeo) formando vídeo-livros (ALBRES, 2015), envolve também a tradução, interpretação e adaptação de histórias para contação, sejam elas individuais, com ou sem adereços, contadas em dupla que enuncia nas duas línguas ou em dupla em que um conta a história em uma língua e o intérprete em outra língua, as duas formas são contações bilíngues. O campo da tradução literária e Libras é um dos mais desenvolvidos com significativa e diversificada produção (SANTOS, 2018).

Um dos campos mais antigos de atuação, no Brasil, refere-se à interpretação de músicas. Destacamos esse campo como pioneiro pelo início dos TILSPs na religião e atuação em igrejas em que as cerimonias religiosas são compostas por diversas músicas, inclusive gerindo corais de surdos com apresentações em Libras (ASSIS SILVA, 2012). Atualmente, a tradução de canções tomou as redes sociais e a publicação em websites, em menor número shows e festivais de música com interpretação simultânea.

A poesia é uma área sensível que requer recriação, primando por aspectos fonológicos e métricos (CAMPOS, 2010), como também é necessária uma "totalização essencial" que fundamentalmente envolve equilíbrio entre as equações fonológicas e semânticas (LARANJEIRA, 2012). Apesar de compor uma mesma esfera, as atividades e competências de cada uma das áreas são bem distintas. A poesia requer mais habilidades de foco na língua, em comparação à música.

Por sua vez, para Bassnett (2011), no teatro como processo coletivo de criação, é preciso compreender que "traduzir para o teatro não é como traduzir poesia ou narrativa; não 
é, e não deve ser, um trabalho solitário. A natureza colaborativa do teatro significa que idealmente o tradutor deve estar engajado no processo, assim como o resto do conjunto" (BASSNETT, 2011, p. 100). Ou seja, para que a tradução do texto de teatro não perca de vista suas especificidades, não poderíamos afastar seu caráter performativo, incluindo nesta todos os elementos de ordem cênica que a atravessarão e a interação com os personagens do espetáculo.

O cinema requer um trabalho intenso de tradução inter-semiótica e interlingual², conhecimentos de tradução audiovisual em língua de sinais (TALS). Nascimento e Nogueira (2019, p. 114) descrevem o movimento histórico de construção dessa prática, como ampliação das possibilidades de consumo das produções audiovisuais no Brasil. Reflexo da Lei brasileira de Inclusão (LBI) houve a "necessidade de o mercado de produções audiovisuais nacionais, especialmente as que possuem fomento público, gerar acessibilidade para pessoas com limitações sensoriais auditivas e visuais". Anjos (2017) e Nogueira (2018) indicam a necessidade de se ter conhecimento sobre espaços de tela, vestimenta e performance além das competências tradutórias.

A atuação nessa gama de eventos artístico-culturais envolve a preparação de intérpretes por meio de curso de formação, crucial para o desenvolvimento da profissão, com ênfase em programas educacionais consolidados e planejados para cobrir as necessidades dos surdos à serviços de qualidade. As investigações empíricas orientadas para as demandas do mercado de trabalho como também para a prática dos TILS são fundamentais não apenas para aumentar a compreensão teórica do desempenho dos intérpretes, mas também para fornecer pontos de referência para profissionais e estudantes (NAPIER; MCKEE; GOSWELL, 2006).

Linden (2014) estudou o currículo do curso de graduação em Letras Libras bacharelado) da UFSC e entrevistou egressos que demonstraram descontentamento com a pouca relação da formação com a vida profissional, visto que as demandas e desafios práticos, geralmente, não são contemplados em disciplinas na formação superior.

Com essa breve descrição dos campos de atuação na esfera artístico-cultural cabe perguntar que tipo de formação abrangeria todas as especificidades de cada atividade? Nesse sentido, propomos o estudo da formação de TILSP para atender essa esfera da vida social de acesso aos bens artístico-culturais pela comunidade surda, outrora privada de acesso e fruição, ou seja, privada de seus direitos por ser uma minoria linguística.

\section{Caracterizações da pesquisa}

A presente pesquisa é de natureza qualitativa, do tipo descritiva e exploratória, com abordagem teórica e fundamentada em dados primários. A partir de um estudo documental, focado nos currículos de cursos de formação superior de tradutores e intérpretes de Libras-

\footnotetext{
${ }^{2} \mathrm{~A}$ tradução interlingual "consiste na interpretação dos signos verbais por meio de alguma outra língua" [...], e a tradução inter-semiótica "consiste na interpretação dos signos verbais por meio de sistemas de signos nãoverbais" (JAKOBSON, 2005, p. 65).
} 
Português no Brasil e de formação livre em Florianópolis - SC, buscamos compreender o tipo de conteúdo e formação disponível para TILSP.

Analisamos a grade curricular de 10 cursos de graduação. A seleção dos conteúdos se deu a partir dos projetos dos cursos, utilizando-se do critério de busca na opção "Título da disciplina" e "ementa". Nessas opções, foram inseridas palavras que indicassem referência à esfera artístico-cultural, tais como "música", "teatro", "poesia". Na sequência, as disciplinas selecionadas foram avaliadas individualmente, em termos de tema, relação teoria-prática de tradução, carga horária, período do curso em que ocorre, buscando averiguar a maneira como foram elaboradas.

Após esse panorama geral e nacional, buscamos identificar outros espaços formativos para além do curso de graduação, considerando ser importante olharmos para a formação baseada no tripé da universidade: Ensino, Pesquisa e Extensão. Tomamos como amostra a cidade de Florianópolis, onde há o curso de graduação Letras Libras bacharelado (UFSC).

Mapeamos as ações desenvolvidas a partir de atividades acadêmicas realizadas na Universidade Federal de Santa Catarina (UFSC) e na Universidade Estadual de Santa Catarina (UDESC) em Florianópolis. Levantamos também eventos culturais com interpretação, âmbito de projetos de extensão e de eventos artísticos da cidade por meio de folder, flyers de espetáculos que circulam na comunidade surda e acadêmica.

O presente estudo constituiu-se de três etapas básicas: 1) Pré-análise: em que foram definidos o tema, o referencial teórico, os objetivos, a metodologia, bem como as estratégias de coleta dos dados; 2) Análise descritiva: organização e descrição dos dados coletados (cursos e eventos artísticos), envolvendo a codificação por meio da classificação (intensidade e direção de ideias) e categorização (definição de categorias a serem trabalhadas); 3) Interpretação inferencial: compreensão dos fenômenos a partir dos materiais teóricos e empíricos, busca de respostas às questões de pesquisa levantadas, verificação de contradições e, por fim, realização das conclusões.

Dessa forma, a coleta de dados se deu por meio de pesquisa documental, e o método de análise utilizado foi a análise dialógica da linguagem (BAKHTIN, 2017). Visamos organizar os dados e analisar os resultados obtidos, a partir de categorias de análise do 1) mapeamento de conteúdos de contexto artístico-culturais em Cursos de graduação para formação de tradutores e intérpretes de Libras-Português, e 2) Cursos Livres e de extensão universitária: i) Espaços para formação livre: minicursos e oficinas, e ii) Espaços para viver a arte e cultura em Libras. A seguir, apresentamos a análise desenvolvida. Optamos por manter os nomes reais dos TILSP e dos formadores (professores) considerando que são dados públicos e este artigo também se configura como um registro histórico da atuação dos primeiros intérpretes nesta esfera em Florianópolis.

\section{Possibilidades de formação na esfera artístico-cultural}

Um dos desafios da formação é preparar o sujeito para os problemas da atuação 
profissional. No campo da arte e cultura não é diferente. A seguir, apresentamos os dados da primeira categoria de análise.

Mapeamento de conteúdos de contexto artístico-culturais em cursos de graduação para formação de tradutores e intérpretes de Libras-Português

A formação de intérpretes de Libras-Português encontra-se em expansão, apesar de não atender a todo o Brasil. A seguir, apresentamos um quadro com os cursos levantados.

Quadro 1: Criação ou reformulação dos cursos superiores de formação em Tradução e interpretação em língua brasileira de sinais - Libras/língua portuguesa em Universidades Públicas

\begin{tabular}{|c|c|c|c|c|c|c|c|c|c|}
\hline 2008 & 2009 & 2012 & 2013 & 2014 & 2014 & 2014 & 2014 & 2014 & 2019 \\
\hline UFSC & UFSC & UFSC & UFRJ & UFG & UFES & UFRR & UFSCar & UFRGS & UFSC \\
\hline $\begin{array}{l}\text { LETRAS } \\
\text { - LIBRAS } \\
\text { (a } \\
\text { distância) }\end{array}$ & $\begin{array}{l}\text { LETRAS - } \\
\text { LIBRAS } \\
\text { (presencial) }\end{array}$ & $\begin{array}{l}\text { LETRAS - } \\
\text { LIBRAS } \\
\text { (presencial) } \\
\text { reformulado }\end{array}$ & $\begin{array}{l}\text { LETRAS - } \\
\text { LIBRAS } \\
\text { (presencial) }\end{array}$ & $\begin{array}{l}\text { LETRAS: } \\
\text { TRADUÇÃO E } \\
\text { INTERPRETAÇÃO } \\
\text { EM LIBRAS/ } \\
\text { PORTUGUÊS } \\
\text { (presencial) }\end{array}$ & $\begin{array}{l}\text { LETRAS - } \\
\text { LIBRAS } \\
\text { (presencial) }\end{array}$ & $\begin{array}{l}\text { LETRAS - } \\
\text { LIBRAS } \\
\text { (presencial) }\end{array}$ & $\begin{array}{l}\text { TRADUÇÃO E } \\
\text { INTERPRETAÇÃO } \\
\text { EM LÍNGUA } \\
\text { BRASILEIRA DE } \\
\text { SINAIS - } \\
\text { LIBRAS/LÍNGUA } \\
\text { PORTUGUESA } \\
\text { (presencial) }\end{array}$ & $\begin{array}{l}\text { LETRAS } \\
\text { (presencial) }\end{array}$ & $\begin{array}{l}\text { LETRAS - } \\
\text { LIBRAS } \\
\text { (a } \\
\text { distância) } \\
\text { reformulado }\end{array}$ \\
\hline
\end{tabular}

Fonte: Elaborado pela autora (2020).

Na primeira categoria, levantamos os conteúdos pela busca das seguintes palavras: artes (1), artístico-culturais (1), teatro (1), música (1), show (0), contação de histórias (0), filme (0), cinema (0), dramaturgia (1). Apresentamos os resultados encontrados das disciplinas e respectivos conteúdos relacionados à esfera artístico-cultural e, logo em seguida, a discussão e análise das implicações para a formação de TILSP nesses cursos superiores (graduação).

Quadro 2: Curso de Letras Libras - bacharelado da Universidade Federal de Santa Catarina modalidade a distância $(2008,2012)$

5o PERÍODO - Literatura Surda: Diferentes tipos de produção literária em sinais: estórias visualizadas, o conto, as piadas, as poesias. As diferentes etapas utilizadas pelo contador de estórias para crianças surdas. Exploração visual e espacial das diferentes narrativas surdas: redescoberta da criação literária surda. Fonte: UFSC (2008) e UFSC (2012).

Quadro 3: Curso de Letras Libras - bacharelado da Universidade Federal de Santa Catarina modalidade a distância (2019a reformulado)

5o PERÍODO - Literatura Surda: Diferentes tipos de produção literária em sinais: o conto, as piadas, as poesias. A expressividade estética e literária nas línguas de sinais. A estrutura e funções de literatura surda e sinalizada. Os contextos e origens de literatura surda e sinalizada. (72h)

60 PERÍODO - Tradução Literária: Teorias da tradução literária. O texto literário em suas especificidades com vista à tradução. A tradução literária no Brasil. A autoria na tradução. Paratexto da obra traduzida. Notas do tradutor. Gênero e forma literária. Tradução e literatura comparada. (72h)

Fonte: UFSC (2019a). 
Quadro 4: Curso de Letras Libras - bacharelado da Universidade Federal de Santa Catarina modalidade presencial $(2009,2012)$

3o PERÍODO - Estudos da Interpretação I: História dos Estudos da Interpretação. Constituição do profissional intérprete de língua de sinais. Aspectos legais e a regulamentação da profissão. Interpretação comunitária. Papéis em diferentes espaços de atuação: intérprete generalista e intérprete educacional. (72h)

70 PERÍODO - Literatura Surda I: Introdução à Literatura Surda. A expressividade estética e literária nas línguas de sinais. $O$ gênero narrativo: estrutura e funções. Realidade e ficção. Tipos de narrativa em línguas de sinais. Narrativas e educação de surdos. Produção e análise de narrativas. A literatura como um artefato cultural. (72h)

8ㅇ PERÍODO - Literatura Surda II: Literatura surda no Brasil e no mundo. O gênero poético. Funções da poesia. Tipos de poesia em línguas de sinais. Poesia e criatividade linguística. Prática em poesia. A expressividade no humor. Metáforas e outros recursos literários em línguas de sinais. (72h)

8o PERÍODO - Prática de Tradução II: Prática tradutória envolvendo a escrita de sinais. Estudos de expressões literárias da cultura surda. Interfaces entre a prática e o desenvolvimento de pesquisas em escrita de sinais e do português. Edição de textos e direitos autorais. (144h)

$$
\text { Fonte: UFSC (2009) e UFSC (2012). }
$$

Apesar de termos 10 projetos de cursos, esclarecemos que o projeto da UFSC 2008 (curso EAD) e UFSC 2009 (curso presencial) utilizam a mesma grade curricular.

Quadro 5: Curso de bacharelado em Letras-Libras da Universidade Federal do Rio de Janeiro (2013) 10 PERÍODO - Fundamentos dos Estudos Literários: Introdução aos conceitos fundamentais da literatura. Abordagem da problemática dos gêneros literários. Noções sobre o poema, a narrativa e o drama. A importância da abordagem interdisciplinar nos estudos literários. (60h)

2ํ PERÍODO - Estudos dos Clássicos da Literatura: Discussão sobre o significado do conceito de clássico na literatura e em outras artes. Debate acerca da importância da leitura dos clássicos. Análise crítica de obras relevantes da literatura mundial. A poesia, o teatro e o romance e suas leituras nas diferentes mídias (cinema, televisão, internet). (30h)

6o PERÍODO - Literatura Surda I: Diferentes produções literárias de autores culturalmente surdos, com ênfase no conto, na piada, no poema e na dramaturgia. (60h)

70 PERÍODO - Literatura surda II: As narrativas surdas: redescoberta da criação literária surda, explorando diferentes elementos da língua de sinais (configurações de mão, movimentos, pontos de articulação). Enfoque na produção em vídeos. As diferentes etapas utilizadas pelo contador de estórias para crianças surdas. Exploração visual e espacial das diferentes narrativas. (90h)

70 PERÍODO - Laboratório Tradução e Interpretação de Libras LP IV: Teoria e prática de tradução e interpretação de Libras-português-Libras em contextos artístico-culturais: literatura, teatro, música. (90h)

Fonte: UFRJ (2013).

Quadro 6: Curso de bacharelado em Letras: tradução e interpretação em libras/português da Universidade Federal de Goiás (2014)

10 PERÍODO - Introdução aos Estudos Literários: Introdução aos conceitos fundamentais da literatura. Abordagem da problemática dos gêneros literários. Leituras e estudos sistemáticos do poema, da narrativa e do drama. (64h)

3o PERÍODO - Libras Intermediário 1: Desenvolvimento de práticas de compreensão e produção em LIBRAS por meio do uso de textos e suas funções comunicativas em nível intermediário. Morfologia da Libras. Introdução aos gêneros textuais em Libras: narrativas, piada e poesia. Escrita de sinais. (64h)

5o PERÍODO - Libras Avançado 1: Prática de compreensão e produção da Libras nas modalidades escrita e em sinais, por meio do uso de estruturas em funções comunicativas em nível avançado. A semântica e a pragmática da Libras. Gênero textual: poesia. Escrita de sinais. (64h)

Fonte: UFG (2014). 
Quadro 7: Curso de bacharelado em Letras Libras da Universidade Federal do Espírito Santo (2014) 3o PERÍODO - Libras e Produção Literária: Diferentes tipos de produção literária em sinais: estórias visualizadas, o conto, as piadas, as poesias. As diferentes etapas utilizadas pelo contador de estórias para crianças surdas. Exploração visual e espacial das diferentes narrativas. As narrativas surdas: redescoberta da criação literária surda. (60h)

5o PERÍODO - Tradução de Textos Literários: Discussão de temas referentes à transposição de obras e textos literários fontes para textos traduzidos e/ou adaptados. Música como gênero literário e a tradução/interpretação. Análise de tradução de textos literários clássicos para a Língua de Sinais; aplicação de modelos teóricos e de estratégias de tradução; tradução de textos literários clássicos para o português ou para a Língua de Sinais. (60h)

Fonte: UFES (2014).

Quadro 8: Curso de bacharelado em Letras/Libras da Universidade Federal de Roraima (2014) 40 PERÍODO - Literatura Surda: Diferentes tipos de produção literária em sinais: estórias visualizadas, o conto, as piadas, as poesias. As diferentes etapas utilizadas pelo contador de estórias para crianças surdas. Exploração visual e espacial das diferentes narrativas. As narrativas surdas: redescoberta da criação literária surda. (60h)

Fonte: (UFRR, 2014).

Quadro 9: Curso de tradução e interpretação em língua brasileira de sinais - Libras/ língua portuguesa da Universidade Federal de São Carlos (2014)

8o PERÍODO - Literatura em Libras: Clássicos da literatura nacional, poesia, metáforas em Libras. Estudos das manifestações artístico-culturais em Libras relativas à esfera literária. (60h)

Fonte: UFSCAR (2014).

Quadro 10: Curso de Letras com habilitação em tradutor e intérprete de Libras (libras-português e português-libras) da Universidade Federal do Rio Grande do Sul (2014)

6o PERÍODO - Literatura Surda: Introdução à Literatura Surda. A expressividade estética e literária nas línguas de sinais. O gênero narrativo: estrutura e funções. Realidade e ficção. Tipos de narrativa em línguas de sinais. Narrativas e educação de surdos. Produção e análise de narrativas. A literatura como um artefato cultural. Literatura surda no Brasil e no mundo. $O$ gênero poético. Tipos de poesia em línguas de sinais. Metáforas e outros recursos literários em línguas de sinais. (60h)

Fonte: UFGRS (2014).

Constatamos que a formação na graduação aborda superficialmente a atuação de TILSP na esfera artístico-cultural, mesmo porque os cursos de graduação, em sua maioria, são generalistas e primam por disciplinas de áreas com campos de trabalho mais consolidados historicamente, como a interpretação educacional, na saúde e jurídico-governamental. As disciplinas que abordam a produção artística em Libras, a literatura ou as produções estéticas nem sempre o fazem na relação entre línguas, ou seja, em processos de tradução e interpretação, mas sim em seus fundamentos ou conceitos. Contemplam uma formação para atuação tradutória-interpretativa nessa área mais voltada para o campo da literatura, talvez pelo processo tradutório não demandar a saía a campo e ser supostamente mais controlável por trabalhar com textos escrito e pela tradução da literatura no campo das letras.

Há outras disciplinas no currículo não relacionadas nesta pesquisa que são descritas de forma bem genérica, e cada professor que as assumir pode conduzi-las de forma a dar contornos mais voltados para a esfera artístico-cultural. Por exemplo, as disciplinas de práticas de tradução são abrangentes podendo abordar diferentes gêneros escritos, por sua vez, as 
disciplinas de interpretação já têm bem delimitadas as esferas de atuação (educacional, saúde e jurídica-governamental).

Para ilustrar esse fato, apresentamos a ementa da disciplina "Prática de Tradução I" do 5 o período do curso de Letras Libras UFSC-EAD com a ementa "Prática tradutória Português-Libras-Português com foco em gêneros textuais variados. O processo tradutório: produção de inferências, solução de problemas e tomada de decisões. Uso de diferentes procedimentos técnicos de tradução" (UFSC, 2019a). A partir dessa ementa, o professor pode trabalhar essencialmente com texto literário, poesias e músicas, por exemplo.

As disciplinas de Libras também trabalham com os textos/discursos da esfera artísticocultural, visto que encontramos de forma recorrente nas ementas o trabalho com a poesia dentre as atividades. Contudo, podem ser conteúdos teóricos e não de tradução ou interpretação entre línguas.

Outro ponto importante de discussão se refere às disciplinas optativas que devem integrar o currículo do aluno. O projeto do curso apresenta a opção de 13 disciplinas que são ofertadas esporadicamente. Vale citar que a UFSC, no Centro de Comunicação e Expressão (CCE), tem o curso de graduação em cinema, teatro, literatura e design absorvendo essa carga horária a depender da escolha do próprio aluno. Dentre as disciplinas optativas ofertadas pelos professores do curso Letras Libras, vale citar "Introdução à Tradução de Literatura Infanto-Juvenil" (72h) idealizada e ministrada pela professora Neiva de Aquino Albres e "Tradução Audiovisual" (72h) idealizada e ministrada pelo professor José Ednilson Gomes de Souza Junior.

Para Silva-Neto (2017, p. 51), a formação básica em curso de graduação deveria contemplar o conhecimento para o estético, para o trabalho com textos sensíveis, só assim o "o tradutor de Libras poderá estruturar o projeto de tradução de forma conectada a proposta da companhia com quem trabalhará". Indica como elementos fundamentais para a formação o conhecimento sobre teatro e teatralidade, sobre texto dramático, conscientização corporal e estética, aspectos cenográficos (luz e figurino), entre outros aspectos.

Os cursos de Letras-Libras nas universidades mencionadas não possuem disciplinas relacionadas à esfera artístico-cultural com base em tradução e interpretação em seu currículo, apenas conteúdos voltados para literatura surda ou a caracterização de alguns gêneros discursivos pertencentes à esfera artística como: poesia, conto etc. Parece, no entanto, que o conhecimento de tradução e interpretação no meio artístico se constrói a partir das práticas em si e de formação paralela em cursos livres. Mas, não podemos afirmar que aos alunos não é oportunizada a aprendizagem desse tipo de atuação, considerando também as atividades de extensão da universidade. "As ações extensionistas [...] potencializam os saberes em construção dos Estudos da Tradução e Interpretação em Língua de Sinais (ETILS) em todo o território brasileiro" (SANTANA; VIEIRA-MACHADO, 2018, p. 249).

Alguns professores coordenam grupos de pesquisa e/ou promovem atividades de extensão em que os alunos da graduação e pós-graduação estão diretamente envolvidos, sendo inclusive obrigatória a participação, mas de livre escolha conforme disponibilidade dos 
alunos, visto que até o final do curso precisam integralizar Atividades Acadêmico-CientíficoCulturais (AACCS).

\begin{abstract}
As Atividades Acadêmico-Científico-Culturais, [...] são componentes curriculares que possibilitam o reconhecimento, por avaliação, das habilidades, conhecimentos e competências dos alunos, inclusive adquiridas fora do ambiente escolar. As AACCs abarcam a prática de estudos e atividades independentes, opcionais de interdisciplinaridade, especialmente nas relações com o mundo do trabalho e com as diferentes manifestações e expressões culturais e artísticas, com as inovações tecnológicas, incluindo ações de extensão junto à comunidade (UFSC, 2019b, p. 1).
\end{abstract}

As AACCs propiciam, além de uma flexibilidade curricular, oportunidade para o acadêmico desenvolver uma atitude de maior autonomia, como agente de sua própria formação profissional, estimulando a participação em outras atividades educacionais que não sejam aquelas previstas no currículo, possibilitando um aprofundamento temático e interdisciplinar. De acordo com o Projeto Pedagógico do Curso, os alunos deverão cumprir um total de 210 horas durante o período de realização do curso e indica, por exemplo, a participação em diferentes manifestações e expressões culturais e artísticas:

A inserção de alunos de graduação em projetos extensionistas reforça conhecimentos adquiridos no ensino, incentiva o exercício de formações e de suas continuidades, desenvolve a criticidade e fomenta temáticas dos fazeres profissionais dos TILPS, sobretudo reflexões acerca de objetos de estudo do ponto de vista teórico e prático dos ELTILS (SANTANA; VIEIRA-MACHADO, 2018, p. 249).

Nesse sentido, levantamos também os espaços de cursos e extensão mais voltados à prática, que contribuam com a formação de TILPS nas esferas artística e literária em Florianópolis. Apesar de os alunos poderem participar de qualquer curso nacional ou internacional, levantamos alguns cursos localmente de formação que relacionam a arte e cultura e tradução e interpretação em Libras.

Consideramos que o curso de graduação é uma iniciação, qualquer aprofundamento, especialização e expertise requer vivências diversificadas e constantes. Nesse sentido, a participação em palestras, minicursos, e, principalmente, em espaços culturais em que circulam Libras e português para se observar modos de atuar na esfera artístico-cultural são fundamentais para a formação. Conforme levantado, o curso de Letras Libras presencial da UFSC requer que o aluno agregue à sua formação 240 horas de disciplinas optativas e 210 horas de Atividades Acadêmico-Científico-Culturais, ou seja, são 450 horas de formação a livre escolha. A seguir, apresentamos algumas dessas opções.

Cursos Livres e de extensão universitária para formação para tradução e interpretação na esfera artístico-cultural

A circulação da divulgação de cursos de extensão e eventos acadêmicos se dá, atualmente, principalmente, pelas redes sociais (Facebook, Instagram, entre outros), nos sites das instituições e companhias ou empresas de cultura da cidade. Dessa forma, para ter acesso 
aos cursos, é preciso estar conectado e ter uma boa rede de comunicação. Por isso, desenvolvemos um recorte, levantando os eventos na região sul, mais precisamente, da cidade de Florianópolis. A cidade sedia eventos artístico-culturais e acadêmicos internacionais, o que proporciona aos alunos um rico espaço de formação fora da sala de aula, de contato direto com os profissionais que já atuam na área e com pesquisadores.

Em Florianópolis, as universidades (UFSC e UDESC) são os espaços de maior desenvolvimento de curso e extensão destinados à formação livre dos tradutores e intérpretes que se interessam por essa área. A seguir, apresentamos os eventos, iniciando em 2014 (não encontramos atividades antes desse ano). Em pesquisa, Rigo (2013, sp.) afirma que até esse período "não ha[via] ações de acessibilidade comunicacional e, embora em alguns locais investigados existam iniciativas e projetos de inclusão, o trabalho do intérprete de Libras nos espaços artístico-culturais da capital catarinense parece ainda ser incipiente e pouco conhecido".

Atividades formativas vão desde participar de oficinas ou assistir a peças e shows com performances de TILSP. Dividimos esses espaçostempos formativos em i) Espaços para formação livre: minicursos e oficinas, ii) Espaços para viver a arte e cultura em Libras.

Espaços para formação livre: minicursos e oficinas

Em 2014, o I Colóquio Internacional de Teatro de Animação, conhecido como FITA Floripa, além dos espetáculos, envolveu atividades de formação. Na 5a , 60 e 8a edição do FITA Floripa, ocorreu oficinas e teatro de bonecos com a professora Dra. Sassá Moreth da UFSC, voltados para o público surdo e para refletir a inserção da Libras.

Figura 1 - Folder do Festival de Folclore Sinalizado desenvolvido pela UFSC

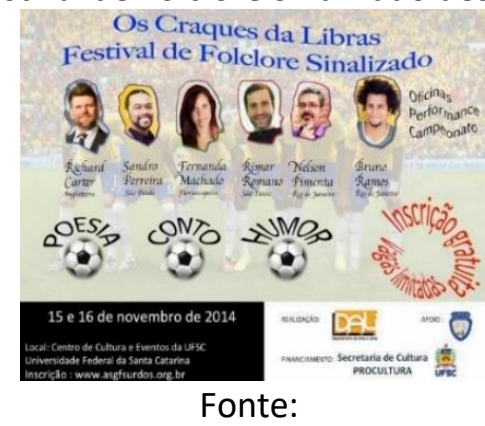

https://www.facebook.com/112968902115973/photos/a.212993325446863/719637298115794/?typ e=1\&theater. Acesso em: 01 set. 2020.

Em 2014, também ocorreu o primeiro Festival de Folclore Sinalizado (20 horas) na Universidade Federal de Santa Catarina, com oficinas, performance e campeonato. Houve oficina de "Piada e humor surdo" com Bruno Ramos e Sandro Pereira, "Narrativas e contos da comunidade surda" com Rimar Romano e Nelson Pimenta, "Poesias sinalizadas" com Fernanda Machado e Richard Carter.

Em 2015, na Semana de Letras da UFSC, aconteceu o minicurso "Tradução de 
Literatura infanto-juvenil para Libras em meio digital", especificamente em atividade de leitura e tradução a partir do livro "O Pequeno Príncipe" (SAINT-EXUPÉRY, 2009) ministrado por Neiva de Aquino Albres ${ }^{3}$.

Registramos como evento pioneiro o Congresso Nacional de pesquisas em tradução e interpretação de Libras e língua portuguesa organizado pela UFSC. Tendo em sua edição de 2016 e 2018 minicursos dedicados às atividades nessa área. Na 5a edição (2016), houve um minicurso, no dia 28 de novembro de 2016. O minicurso 2 foi: "Literatura Surda", ministrado pelas professoras Fernanda Araújo Machado e Rachel Sutton-Spence (Fonte: https://www.evecon.com.br/projecta/tilsp2016/programacao/index.php). Na 6a edição (2018), houve dois minicursos. O minicurso 3 foi "Tradução/Interpretação de Libras/Português na Esfera Artística"4 (14h às 18h) ministrado pela Prof. Natália S. Rigo da Universidade do Estado de Santa Catarina, e o Minicurso 5 foi "Literatura Surda"5 (14h às 18h), ministrado pela Professora Rachel Sutton-Spence (UFSC).

No ano de 2016, aconteceu também o Festival de Folclore Surdo na Universidade Federal de Santa Catarina. Foram 32 horas de oficinas, aulas com mestres artistas e apresentações em língua de sinais, realizado de 10 a 13 de dezembro de 2016.

Figura 2 - Eventos da UFSC em 2016 e 2018

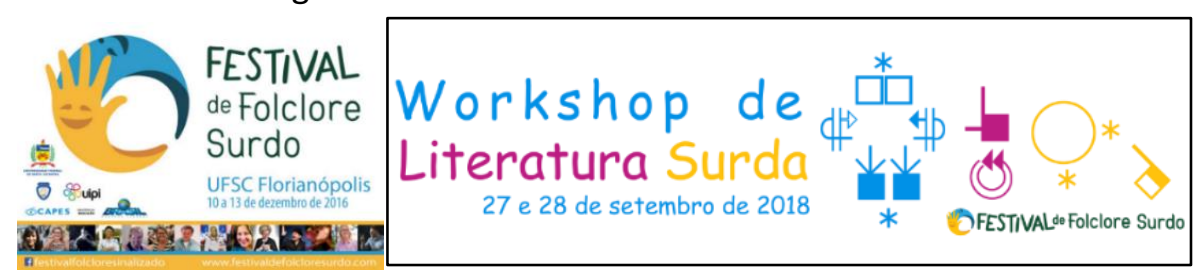

Fonte: https://festivaldefolcloresurdo.com/ e https://workshopdeliteraturasurda.com/.

Acesso em: 01 set. 2020.

\footnotetext{
${ }^{3}$ Minicurso: Tradução de Literatura infanto-juvenil para Libras em meio digital. Tivemos como objetivo conduzir os participantes do minicurso a compreender os aspectos enunciativos e discursivos da interpretação da língua de sinais e as especificidades de atuação do tradutor/ intérprete em materiais literários e didáticos tendo como público-alvo crianças surdas. Pretendemos explorar aspectos da verbo-visualidade em materiais literários e digitais. O minicurso foi desenvolvido com atividade prática de tradução coletiva e registrado em vídeo emergindo da interação a reflexão teórico-prática, colaborando assim para a formação de tradutores e professores de Libras.

${ }^{4}$ Ementa: O minicurso Tradução/Interpretação de Libras/Português na Esfera Artística foi realizado em dois momentos. No primeiro momento abordamos possibilidades de contextos de atuação do TILS. Por meio de um jogo dinâmico, foi elaborado um mapeamento de possíveis linguagens artísticas, locais de atuação e tipos de eventos, que foram combinados e relacionados entre si. O objetivo foi levantar diversas questões imbricadas na atuação nessa esfera no que concerne a: demandas e exigências ambientais, intrapessoais e interpessoais. No segundo momento, discutimos sobre possíveis ações e práticas referentes às demandas e exigências tradutórias e linguísticas a partir de situações-problema relacionadas às combinações, de linguagem artística, local e tipo de evento, mapeadas no primeiro momento.

${ }^{5}$ Ementa: A oficina apresentou uma introdução teórica sobre as normas literárias surdas e as normas de tradução necessárias para um "ator tradutor" junto com uma atividade de tradução prática, no qual traduziremos algumas frases de um texto clássico da literatura brasileira. Consideramos os desafios para os tradutores da Libras a partir de: o uso lúdico da forma e do significado da língua Portuguesa; os dialetos incomuns do português; o conhecimento assumido dos membros da comunidade surda; o conhecimento dos tradutores sobre as normas literárias da cultura surda; o papel do tradutor-ator literária de Libras.
} 
No ano de 2018, os idealizadores do Festival tinham organizado uma segunda edição também com convidados internacionais. Contudo, por falta de financiamento, não puderam realizar o evento de grande magnitude, realizando um Workshop local de Literatura Surda nos dias 27 e 28 de setembro de 2018.

No estado de Santa Catarina, ainda contamos com o Encontro de TILS da Esfera Artística. "O evento tem por objetivo promover a esfera artística como campo de atuação legitimado possibilitando trocas de experiências, novos conhecimentos teóricos e práticos, reflexões, diálogos, negociações, apresentações e circulação de trabalhos" ${ }^{6}$. Esse evento compreende diferentes atividades, como palestras, sarau e minicursos e é desenvolvido na UFSC por iniciativa dos tradutores e intérpretes que atuam nessa área.

No primeiro encontro "TILS Esfera artística", a programação (2016) envolveu a "Mostra Fotográfica e Audiovisual"; uma mesa-redonda: "A atuação do TILS no teatro: um fazer de muitos dizeres"; a palestra 1 - "As personas do intérprete de Libras em cena no teatro", ministrada por Amanda de Lima Oliveira, Carolina Fomin; a palestra 2 - "Trajetórias de um fazer artístico: entre o silêncio e o querer", ministrada por Hellen Thalita José Araújo, Lenilson da Costa Silva, Lucas Nogueira Xavier ${ }^{7}$ e Sarau de apresentações.

Em sua segunda edição (2018), o evento contou com a palestra: "Tradução da arte e a arte da tradução: potencialidades e possibilidades", ministrada por Jonatas Medeiros, a palestra: "Vivências da Transcriação", de Erika Mota e a palestra: "Libras no Cinema: socializando experiências", de Ângela Russo, como também um Minicurso EAD: "Interpretação na Esfera Artística"8, ministrado pelos tradutores e intérpretes Jonatas Medeiros (PR), Érica Mota (SP), Nathália Rigo (SC) e Carolina Fomin (SP) e sarau de apresentações.

O Programa de Extensão "Sinaliza UDESC: Arte e Formação" também desenvolve diversas atividades, como o "Artes \& Libras em Ciclo", que teve sua primeira edição em 2016, coordenado pela professora Natália Rigo da UDESC (Centro de educação a distância - CEAD), e pensado e organizado em conjunto com estudantes da disciplina de Libras do curso de Artes Visuais da Universidade, que participam diretamente da construção das oficinas, juntamente com demais profissionais Surdos e/ou ouvintes falantes de Libras e atuantes na área artística.

O 1 을 Artes \& Libras aconteceu de 16 a 19 de novembro de 2016 com exposição de artistas da comunidade surda, oficinas de cerâmica, gravura e aquarela, roda de conversa sobre Educação Surda no Teatro e nas Artes Visuais, filmes e sarau de poesias, exibição do curta-metragem "Crisálida" e filme "Tropa de elite" acessível em Libras. O $\underline{\text { 2o Artes \& Libras }}$ aconteceu de 08 a 11 de novembro 2017 com a mesa-redonda "Música e Libras, Teatro e Libras, Sarau em libras e oficinas de desenho, modelagem, cartoon, dança, Clown (a arte de palhaço), teatro, stencil (técnica específica de desenho). 0 o Artes \& Libras aconteceu de 25 a 30 de novembro 2018 com palestras sobre "Mediação em Libras por arte-educador surdos

\footnotetext{
${ }^{6}$ Disponível em: https://www.facebook.com/events/1079457232145961/. Acesso em: 03 nov. 2020.

${ }^{7}$ Disponível em: https://tilsartes.wixsite.com/ufsc/sobre-nos. Acesso em: 03 nov. 2020.

${ }^{8}$ Disponível em: https://tilsartes.wixsite.com/2018. Acesso em: 03 nov. 2020.
} 
em museus" (Leo Castilho), "Arte Surda: música para surdos?" (Jonatas Medeiros), "Tradução musical para Libras: reflexões e práticas", oficina de monotipia, oficina de curta-metragem com temática de Libras e comunidade surda e I mostra de curtas e videoarte. Ainda no ano de 2018, aconteceu a apresentação do espetáculo "lara - O encanto das águas" interpretado por Patrícia Ribeiro Nachtigall e a oficina de teatro de sombras com Thiago Bresani e Soledad Garcia com interpretação de Taiana Beche e Patrícia R. Nachtigall. ${ }^{9}$ O $\underline{40}$ Artes \& Libras aconteceu de 25 de setembro a 21 de novembro 2019 com uma programação espaçada. A programação envolveu palestras como: "O potencial cênico dos surdos, da libras e teatro surdo: representatividade e protagonismo surdos" (Darley Goulart), "O surdo e a relação com a música: compartilhando experiências" (Diogo Assis), "Ver o som: possibilidades estéticas e corporais nas música em libras" (Barbara Helena), "Espetáculo Acessível e o Intérprete de libras no Teatro" (Carolina Fomin), "Musicalidade e ritmo na poesia em Língua de Sinais" (Samuel Morais), "Processo de criação de espetáculo: Libras e sua função cênica" (Ricardo Tetzner), "Coreografia de Sinais: coreografia de dançateatro a partir da Libras" (Ricardo Tetzner), "Intérprete em Cena: parceria de educadores nas aulas de teatro" (Stephanie Vasconcelos), "Teatro mediado: aula bilíngue de teatro e suas implicações" (Stephanie Vasconcelos), "Atuação do consultor e tradutor surdo em shows de música: compartilhando experiências" (João Gabriel), "Grupo Signatores: experiência em cena com atores surdos" (Adriana Somacal), "Alice: possibilidades de um espetáculo teatral em Libras com atores surdos" (Adriana Somacal) e "Música e Libras: a educação em parceria cm o ponte" (Stephanie Vasconcelos). A programação teve 13 palestras, com temas relacionados à música e ao teatro com Língua Brasileira de Sinais (Libras), como processos de tradução e interpretação; produção cultural acessível; e tradutor e intérprete surdo.

No ano de 2019, também ocorreu o $1^{\circ}$ Libras em Dança (de 22 a 29 de abril de 2019). Oficina de Funk em Libras, ministrada por Diogo Assis, Oficina de Dança do Ventre em Libras, ministrada por Natália Rigo; Oficina de Sapateado em Libras, ministrada por Danielle Sousa; Oficina de Flamenco em Libras, ministrada por Marilyn Mafra; Oficina de Dança a Dois em Libras, ministrada por Cacá Rögelin e Gui Rocha e Palestra-Interativa "Libras e sua Função Cênica", tendo com ministrantes Alexandra Klen, Ricardo Tetzner e Natália Rigo.

O Seminário do Curso de Letras-Libras (SELL) da Universidade Federal de Santa Catarina (UFSC) acontece desde o ano de 2016, mas foi em 2019 a primeira edição com minicursos específicos voltados para essa esfera. Em sua 4ㅇe edição, entre os dias 2 a 6 de setembro, dentre os oito minicursos do evento, dois estavam relacionados à literatura e à esfera artístico-cultural. O minicurso "O TILS no Contexto Artístico"10 ministrado por Natália

\footnotetext{
${ }^{9}$ Disponível em: https://www.facebook.com/ealisbr/videos/593165907785924/. Acesso em: 03 nov. 2020.

${ }^{10}$ A tradução e a interpretação nos contextos artístico-culturais, mais especificamente no par linguístico Português-Libras, têm ganhado espaço e visibilidade no cenário brasileiro. Refletir e discutir sobre essas práticas contribui para a formação dos profissionais que atuam na área e para aqueles que se interessam por ela, reverberando significativamente nos produtos apresentados e no mundo do trabalho. Tendo o teatro como foco desses contextos, esta oficina objetiva desenvolver exercícios de preparação e de atuação do tradutor e do intérprete de Português-Libras, bem como promover o diálogo a respeito dos elementos que atravessam e compõem as práticas nesse âmbito. Nesse sentido, também será oportunizada a reflexão sobre aspectos como
} 
Rigo e Samuel Moraes e "Humor em Libras"11 ministrado por Rachel Sutton-Spence.

Em síntese, dentre os anos de 2014 e 2019, constatamos o crescimento de eventos que incorporaram oficinas na área como a expansão de temáticas. Registramos diversas possibilidades de formação na esfera artístico-cultural divididas em palestras, minicursos, oficinas. Constatamos que os palestrantes são provenientes de diferentes regiões do país e de outros países quando são eventos nacionais e internacionais. Portanto, a presente seção tentou delinear o espaçotempo de formação livre ressaltando que, apesar de o curso possuir restrito espaço para formação nessa área, e não possuir disciplina de tradução e interpretação com ênfase artístico-cultural, a formação, neste caso, baseia-se em práticas e também em formação livre (paralela) ao curso de graduação como em cursos livres distribuídos nas regiões sul e outras cidades do Brasil.

\section{Espaçostempos para viver a arte e cultura em Libras}

A aprendizagem de arte em Libras também perpassa pela possibilidade dos TILSP ou alunos de tradução viverem um processo contínuo e cada vez mais aprofundado do conhecimento artístico e estético, seja ele pelo contato com produções artísticas desde a observação até a atuação. Apreciar formas de arte com Libras pode contribuir tanto para o processo pessoal de criação dos aprendizes no processo de tradução como também para o conhecimento significativo da atuação na esfera artístico-cultural.

Neste tópico, apresentamos o levantamento de Saraus, Festivais, Musicais e Peças Teatrais em Libras de Florianópolis (SC) seguindo uma ordem cronológica, ou seja, espaços para se consumir arte e cultura e apreciar modos de expressão artística em Libras como poesias, narrativas em processos de tradução e interpretação. Esses espaçostempos também são formativos, no sentido de proporcionarem aos tradutores e intérpretes o contato com a Libras em cena em seu produto estético e final.

Ainda em 2014, o I Colóquio Internacional de Teatro de Animação, conhecido como FITA Floripa apresentou a peça "O Som das Cores" com a tradução para Libras por Natália Schleder Rigo, um dos primeiros registros dessa atividade. Como mencionado, em 2014, também ocorreu o Festival de Folclore Sinalizado na UFSC, os TILSP tiveram o contato com

\footnotetext{
iluminação, localização do intérprete, figurino e personagens. Fonte: https://sellufsc.wixsite.com/2019. Acesso em: Acesso em: 03 nov. 2020.

${ }^{11}$ Neste minicurso, falamos do humor em Libras, em que o impacto vem primeiramente da forma da linguagem. Seguimos as sugestões do filósofo francês Henri Bergson para entender o que gera os risos em Libras. Morgado (2011) descreveu cinco formas de humor da língua de sinais: imitações de filmes, pessoas, animais e objetos apresentados por expressões faciais e corporais; jogos de linguagem, geralmente contos curtos, que brincam com formas de mão, especialmente o alfabeto manual ou números; jogos com movimento; jogos de linguagem sobre tópicos tabus; piadas, desenhos animados e anedotas humorísticas. Especificamente, focamos em três áreas que geram risos em Libras: 1 ) imitação de pessoas, animais e objetos; 2 ) jogos com a estrutura interna de sinais; 3 ) humor bilíngue que mescle português e Libras. Ainda precisamos muito mais pesquisas em Libras, mas analisamos alguns textos humorísticos baseados nas pesquisas em outras línguas de sinais que possam contribuir aos estudos de humor em Libras. Depois, os participantes tiveram a oportunidade de criar suas próprias peças de humor em Libras. Fonte: https://sellufsc.wixsite.com/2019). Acesso em: 03 nov. 2020.
} 
processos de interpretação vividos entre as línguas de sinais britânica (BSL), língua de sinais americana (ASL) e inglês, Libras e português. No final do evento, houve um espetáculo com os "craques", os melhores das oficinas. "No decorrer do festival Surdos e ouvintes sinalizantes de todas as idades e níveis de conhecimento foram convidados a assistir as performances de histórias, piadas teatro e poesia apresentados por artistas consagrados pelo uso artístico da Libras no Brasil” (SUTTON-SPENCE et al., 2016, p. 87).

O Festival de Folclore Surdo na UFSC, realizado de 10 a 13 de dezembro de 2016, também proporcionou um rico espaço de apreciação artística. "O objetivo era reunir a comunidade surda com artistas surdos, reconhecidos como contadores de histórias e poetas em língua de sinais - do Brasil e de outros países, para compartilhar e aprender sobre o folclore surdo" (FESTIVAL, 2016, s.p.).

Mais recentemente, percebemos um movimento crescente de peças teatrais traduzidas para a Libras. Assistir a espetáculos de companhias de surdos ou traduzidas para a Libras também é uma atividade (espaço) de aprendizagem significativo. É comum a prática, de quando eventos desse porte coincidem com os dias de aulas, dos professores de disporem da aula para a participação dos alunos nos eventos, requerendo como registro de presença um relatório da atividade, em que o aluno pode refletir e registrar os contornos estabelecidos pelo seu processo de construção de sentidos a partir da educação problematizadora oferecida, o relatório pode servir como ponto disparador para uma discussão coletiva em sala de aula.

A prática dos relatórios passa a ter o mérito de contribuir para um "descongelamento" da realidade tratada de forma teórica, restrita e formal durante as aulas, no momento em que consegue levar o aluno a efetivamente trabalhar na sua aprendizagem, co-responsabilizando-se com a expansão do conhecimento para fora da aula, no seu universo particular. Contribui como uma das formas efetivas para a superação do formalismo como acima descrito: privilegia-se o processo de criação do aluno através da habilidade de seleção e manipulação das informações, incentivando-o a um posicionamento individual/pessoal sobre os diferentes assuntos tratados (STUDER; CASAGRANDE, 1999, p. 67).

Essa prática corrobora uma pedagogia significativa e problematizadora, conduzindo os alunos à conscientização e ao envolvimento crítico com sua futura profissão. Seria uma vivência que une teoria e prática em espaço de diálogo e ativa da perspectiva do aluno, como indica Freire (1970).

Desde o ano de 2012, acontecem apresentações do projeto "Domingo é Dia de Teatro", patrocinada pelo município de Florianópolis e pela Fundação Cultural de Florianópolis Franklin Cascaes por meio da Lei Municipal de Incentivo à Cultura no 3659/91 com entrada gratuita. O projeto tem o apoio cultural do shopping Iguatemi Florianópolis e da Escola da Ilha. A coordenação geral é da Marte Cultural. As apresentações acontecem com interpretação para Libras uma vez no mês desde o ano de 2016 e audiodescrição via Rádio FM ${ }^{12}$ (NSC TOTAL,

\footnotetext{
12 Para acessar a audiodescrição, basta ter um celular com rádio e fones de ouvido e sintonizar na frequência informada no dia. A frequência só alcança os limites da sala. Fonte: https://ocp.news/entretenimento/domingoe-dia-de-teatro-tem-espetaculo-acessivel-em-floripa. Acesso em: 03 nov. 2020.
} 
2015). Já atuou no projeto Barbara Perez e, atualmente, atua Viviane Barazzuti, egressas da UFSC.

Figura 3 - "O Rei Leão - o musical”. Apresentação em março e abril de 2019

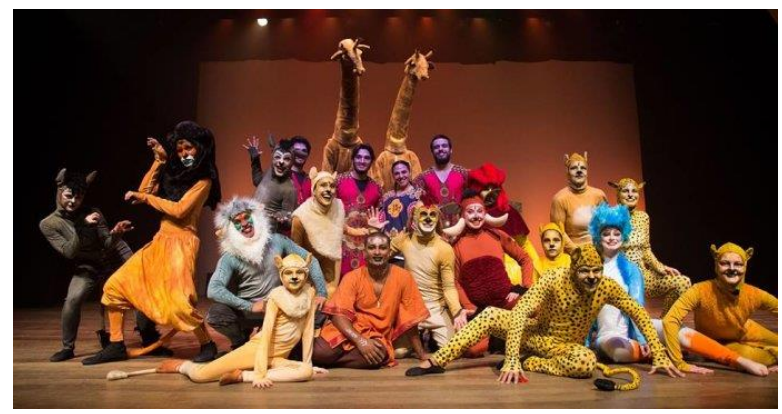

Fonte: http://calendariofloripa.com/board/77-1-0-9537. Acesso em: 01 set. 2020

Ainda no ano de 2016, a RPR produções começou a desenvolver várias produções artístico-culturais, em formato de teatros musicais com interpretação para Libras em Florianópolis. Já produziram "Os Saltimbancos, "Peter Pan”, "O Rei Leão - o musical (figura 3), com interpretação de Wharley dos Santos e "A Pequena Sereia", "Frozen - O Musical" com a interpretação de Deise Leonel, ambos egressos do curso de graduação da UFSC.

Figura 4 - Apresentação de Dança de Salão Cênica com a participação de Tradutora-intérprete de Libras-português

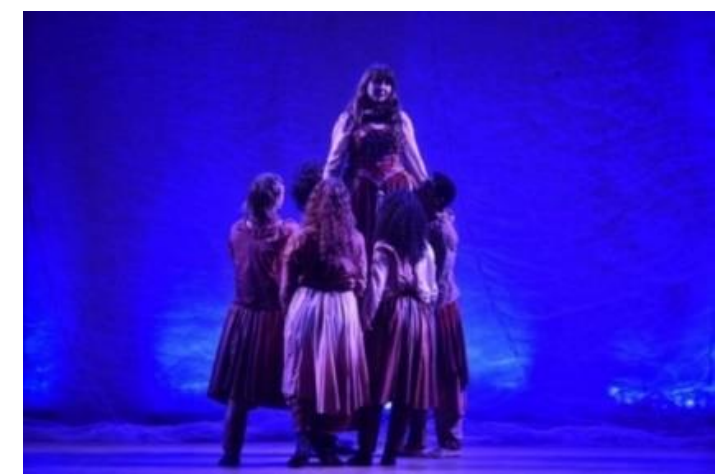

Fonte: http://www.pmf.sc.gov.br/mobile/index.php?pagina=notpagina\&noti=18442.

Acesso em: 01 set. 2020

No ano de 2018, Dois Pontos Cia de DançaTeatro lançou o espetáculo "1717", um espetáculo de Dança de Salão que teve como tema Nossa Senhora Aparecida e trouxe a centralidade da Libras e a integração da tradutora e intérprete-artista Natália Rigo (egressa da primeira turma da UFSC).

Com direção coreográfica de Ricardo Tetzner, '1717' leva para a cena a linguagem da DançaTeatro reelaborando o imaginário sensível e criando o conceito de Dança de Salão Cênica. Nesse diálogo com a contemporaneidade, integra na composição coreográfica a Língua Brasileira de Sinais, não como simples tradução, mas como função cênica e poética (AGENDA DE DANÇA, 2018). 
Nesse projeto discursivo, todos os integrantes sinalizavam em momentos pontuais. $\mathrm{O}$ espetáculo contou com várias apresentações, inclusive no ano de 2019 no $1^{\circ}$ Libras em Dança (25/04/2019).

Em novembro de 2018, aconteceu o Festival Dança Catarina ${ }^{13}{ }_{2}$ com o Espetáculo Insânia Loquaz da "Dois Pontos" da Cia de DançaTeatro que fez sua estreia em Florianópolis no Teatro do SESC Florianópolis (Prainha). Insânia Loquaz é um espetáculo de DançaTeatro, que utiliza a Dança de Salão como linguagem principal e a Libras e que tem como tema a Loucura. Contou com a assessoria do professor Tarcísio Arantes Leite da UFSC e de Rui Zuzza, surdo e egresso do Letras Libras da UFSC.

Figura 5 - Dois Pontos • Cia de DançaTeatro Estreia em Floripa - Espetáculo Insânia Loquaz da

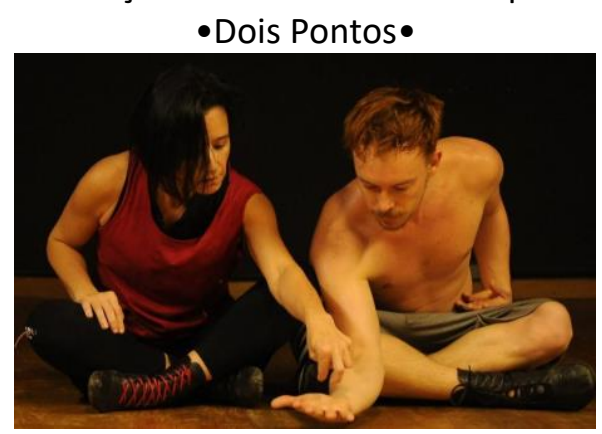

Fonte: Página do Facebook da companhia de Dança. Disponível em:

https://www.facebook.com/ciadoispontos/photos/pcb.281134559273532/780929528907145/

?type=3\&theater. Acesso em: 01 set. 2020

Em, 2019, de 2 a 31 de agosto, Florianópolis sediou o 16a Festival Palco Giratório Sesc com 23 apresentações de teatro, circo, dança, intervenções cênicas para todas as idades como também ações formativas. Dentre elas, o drama com base na obra de Michel Foucault da companhia de teatro Caicó intitulada " $P$ ' $s$ " foi apresentada com interpretação para Libras por Barbara Helena da Silva, aluna da UFSC (BALANÇO GERAL FLORIANÓPOLIS, 2018).

Figura 6 - Interpretação em peça teatral "P's"

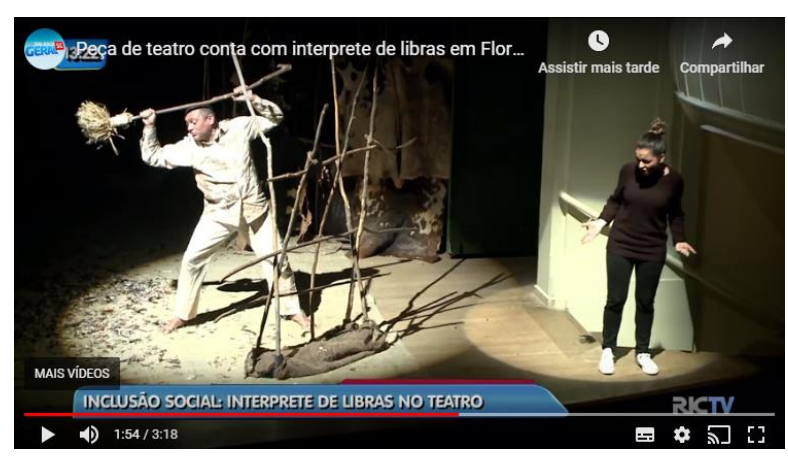

Fonte: https://ndmais.com.br/videos/balanco-geral-florianopolis/peca-de-teatro-conta-cominterprete-de-libras-em-florianopolis/. Acesso em: 01 set. 2020.

\footnotetext{
${ }^{13}$ Disponível em: http://www.dancacatarina.com.br/. Acesso em: 03 de nov. de 2020.
} 
O 24을 Festival Isnard Azevedo, com uma programação de 8 a 29 de setembro de 2019 de 22 espetáculos teatrais, teve 8 peças com tradução para Libras, sendo 11 apresentações. Todas as peças que tiveram a tradução eram acompanhadas do símbolo de acessibilidade no material de divulgação ${ }^{14} \mathrm{e}$, em sua grande maioria, foram interpretadas por ex-alunos do curso de graduação da UFSC. A peça "Quando eu Morrer, vou contar tudo a deus" (O Bonde São Paulo/SP) interpretada por Patrícia Natigali e Bárbara Peres, e, na segunda seção, por Mike Silva de Oliveira e Joanna Bruna Tiepo.

A mostra contou com a peça "A Menina e sua sombra de menino" (Malagueta Produções - Florianópolis/SC) interpretada por Patrícia Natigali e Poliana, segunda seção por Patrícia Natigali e Camila Fernandes. A peça "Kasperl e a cerveja do Papa" (Trip Teatro - Rio do Sul/SC) foi interpretada por Patrícia Natigali e Joanna Bruna Tiepo. A peça "Momo: Para Gilda com Amor" (Selvática Ações Artísticas \& O Estábulo de Luxo - Curitiba/PR) foi interpretada por Bárbara Peres e Mike Silva de Oliveira. "Ogroleto" (Grupo Pavilhão da Magnólia - Fortaleza/CE) foi interpretada por Patrícia Natigali e Camila Fernandes e a segunda seção foi interpretada por Taiana e Bárbara Peres. "Para contar Estrelas" (Grupo Cirandela Criciúma/SC) foi interpretada por Patrícia Natigali e Camila Fernandes, a segunda seção por Taiana e Bárbara Peres. "De tempos somos - um sarau do grupo galpão" foi interpretada por Bárbara Peres e Joanna Bruna Tiepo. As atuações referentes ao espaço do TILS no palco foram bem diversificadas, constatamos desde o posicionamento dos TILS na lateral do palco aos modos de interpretação em interação com os atores. Consideramos que cada projeto discursivo requer um tipo de performance e planejamento com a equipe de produção (figuras 7 e 8).

Figura 7- Apresentações do 24ํFestival Isnard Azevedo com Intérprete na lateral do palco e em dupla (interação)
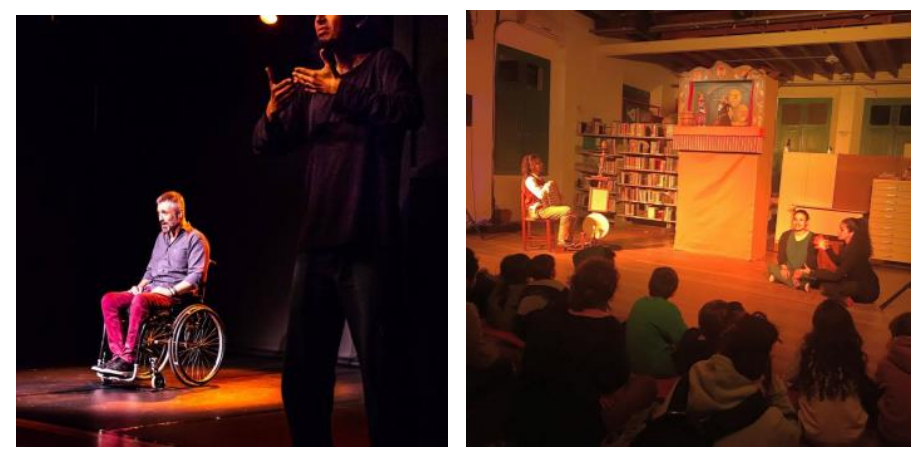

Fonte:

https://www.facebook.com/1497373460587969/photos/a.2196768050648503/2201630163495625/ ?type=3\&theater $\mathrm{e}$

https://www.facebook.com/1497373460587969/photos/a.1497835790541736/2469972096661429/ ?type=3\&theater. Acesso em: 01 set. 2020

\footnotetext{
${ }^{14}$ Disponível em: https://www.facebook.com/Festival-Isnard-Azevedo-1497373460587969/?tn-str=k*F. Acesso em: 03 de nov. de 2020.
} 
Parte do 19a Mostra Em Cena Catarina Sesc trouxe espetáculos gratuitos para a cidade. As peças foram apresentadas em todo o Estado: no dia 25 de outubro, houve o espetáculo "CAÊ", com Karma Cia. de Teatro, dia 26 outubro de 2019, a Téspis Cia. de Teatro apresentou o espetáculo "\#Indice22", e no dia 27 de outubro o espetáculo "O que só passarinho entende", com Cia Artística Cobaia Cênica no Teatro SESC Prainha com a interpretação para Libras do professor Carlos Henrique Rodrigues e Hanna Beer e assessoria dos surdos João Gabriel e Gustavo Gusmão. As companhias de teatro viajam para apresentações e, a cada cidade, podem incorporar novos intérpretes locais. Esse espetáculo, por exemplo, contou com a interpretação em Florianópolis, São Joaquim, Itajaí, entre outros, conforme dados em sua página (SESC, 2019).

É cada vez mais comum nas intervenções artísticas que acontecem em Florianópolis se ter o serviço de TILPS como também a participação de professores da UFSC e UDESC. Em 3 de novembro de 2019, ocorreu o espetáculo musical "Tributo à Sandy e Junior", uma comédia musical que conta a história de Sandy e Junior. O espetáculo teve muitas canções, os sucessos da dupla e foi interpretado por Deise Leonel (egressa da UFSC) e pelo professor Marcos Luchi da UFSC.

Figura 8 - Intérpretes em dupla representando os atores em dupla

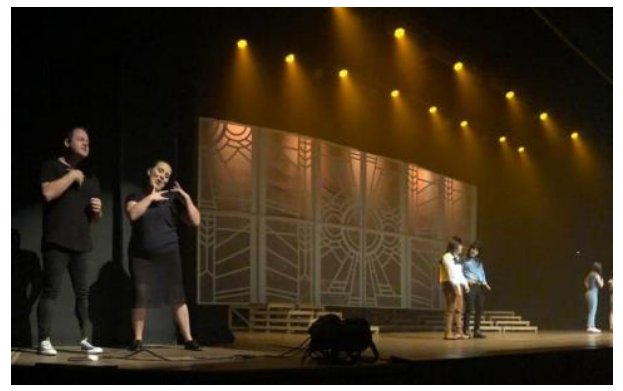

Fonte: Foto de Rodrigo Sambaqui.

Disponível em: https://www.facebook.com/search/top/?q=\%23tributosjfloripa\&epa=SEARCH BOX. Acesso em: 01 set. 2020

Dos espetáculos levantados, os produtores afirmam que a inserção da Libras se deu pelo incentivo financeiro e têm mostrado um crescimento anual tanto em número de espetáculos quanto de diferentes companhias envolvidas e da participação em diferentes festivais. Constatamos que a maioria das apresentações artísticas teve a atuação de ex-alunos do curso de graduação em Letras Libras da UFSC. Também ficam evidentes os diversos tipos de atuação, desde o TILSP integrado ao elenco ("Nossa Senhora"), TILSP compondo a equipe com figurino e maquiagem específicos ("O rei leão - o musical"), como o TILSP na lateral do palco ("P's"), até o TILSP como assessor que orienta aos atores para incorporar a Libras ao espetáculo ("O que só passarinho entende"). Constatamos também que espaços com espetáculos de teatro tem se desenvolvido mais que os shows de música.

A interpretação em espetáculos musicais é ainda mais recente. Em 04 de junho de 2019, aconteceu o evento "Mattinata: canções italianas em concerto" e teve um surdo (João Grabriel Ferreira) e dois intérpretes ouvintes (Lais Benedetto e Barbara Helena da Silva) com 
entrada gratuita (CALENDÁRIO FLORIPA, 2019). Em outubro do mesmo ano, no evento Festival Lula Livre - Santa Catarina, houve intensa programação de bandas e músicas populares e modernas com atuação dos intérpretes Walquíria Peres de Amorim, Tom Mim Alves, Stephanie Caroline Alves Vasconcelos, ex-alunos do curso de Letras Libras da UFSC, e Saionara Figueiredo Santos, Rayssa Tavares Paris. O evento ocorreu em praça aberta e gratuito a todos.

Alguns alunos têm empresas e agenciam o trabalho de TILSPs na cidade. Esse é outro tipo de aprendizagem prática de negociação, contrato e administração que envolve a prestação de serviços de acessibilidade em Libras. Como constatou Linden (2014, p. 23), os TILSP formados dizem sentir a "necessidade de compensar os estudos fora de sala de aula". Podemos afirmar que esse "fora da sala de aula" está cada vez mais institucionalizado com o movimento de curricularização da extensão, com densa carga horária do currículo de AACCs.

\footnotetext{
Tradicionalmente, nas formações de tradutores e intérpretes de Libras, há uma direção muito forte voltada para as técnicas de tradução, isto é, com ênfase em conceitos, prescrições sobre como lidar, como pensar um texto ou outro pela língua "tal ou qual". É fundamental ampliar a discussão da formação dos TILSP aliando a dimensão técnica à dimensão da experiência (SANTANA e VIEIRA-MACHADO, 2018, p. 244).
}

Demonstramos que a concepção de formação para a vida, para as demandas sociais se faz fundamental. A incorporação de carga horária de vivências e cursos extras ao currículo já está institucionalizada, compreendendo 210 horas da carga horária do curso como AACCs. Por outro lado, se faz fundamental que as equipes pedagógicas dos cursos de formação construam uma didática viva, que envolva práticas e reflexões sobre a mobilização de textosdiscursos e não apenas de aplicação de técnicas.

Atualmente há um movimento de curricularização da extensão, ou creditação (curricular) da extensão indicada no Plano Nacional de Educação (PNE), regulamentada pela Resolução no $7 \mathrm{MEC} / \mathrm{CNE} / \mathrm{CES}$, de 18 de dezembro de 2018. Entre outras normativas, a Resolução: (1) estabelece que "as atividades de extensão devem compor, no mínimo, 10\% (dez por cento) do total da carga horária curricular estudantil dos cursos de graduação, as quais deverão fazer parte da matriz curricular dos cursos" (BRASIL, 2018, on-line), também indica a articulação entre atividades de extensão, ensino e pesquisa. As universidades têm trabalhado para reformulação curricular de incorporação dessa carga horária no currículo para além das AACCs já estabelecidas. Essas normativas administrativas valorizam cada vez mais a participação dos alunos em eventos, oficinas e vivências de tradução concomitantes ao curso de graduação e indicam a necessidade de os cursos repensarem seus currículos para além do desenho em disciplinas fechadas a serem ministradas em "salas de aula".

\section{Considerações finais}

Este trabalho acabou por configurar-se como um estudo de didática da tradução, versando sobre o desenho curricular de cursos de graduação de formação de tradutores e 
intérpretes de Libras-português no Brasil e como um estudo histórico, a partir do momento que mapeia e registra os primeiros eventos da esfera artístico-cultural de Florianópolis em que se tem atuação de tradutores e intérpretes, inclusive registrando nominalmente esses profissionais.

Problematiza-se o quão complexo é o campo de atuação na esfera artístico-cultural e suas atuações com diferentes textos-discursos como também que tipo de formação abrangeria todas as especificidades. Para tanto, levantam-se além dos conteúdos curriculares dos cursos de graduação as diferentes oportunidades de formação livre em cursos de extensão e eventos artísticos para viver arte, realizadas em Florianópolis - SC.

O conjunto de conteúdos que estão articulados dentro do contexto de ensino e aprendizagem dos cursos parece voltar-se para aspectos teórico-conceituais. Não se pode negar que a formação registrada no currículo é lacunar e, ao depender de atividades de extensão e das oportunidades de vivência social na esfera artístico-cultural, não se garante efetivamente a participação de todos os alunos nesse tipo de experiência. As oportunidades de vivenciar os processos de tradução encontram-se em minicursos e em atividades de imersão em ambientes artístico-culturais por meio de atividades de extensão ou para comprovação de AACCs

Ao levantarem-se os eventos artísticos na cidade de Florianópolis com TILSP a partir de Festivais, desenvolveu-se um registro histórico, enfatizando o seu crescimento ficando cada vez mais diversificados os tipos de textos-discurso como também as atividades de TILSP, desde a tradução e interpretação, como também de atividades com consultoria, assessoria, administração por meio de criação de empresas e agenciamento de outros TILSP.

A partir dos dados levantados, indicam-se três eixos norteadores da formação dos TILSP: a produção, a fruição e a reflexão. Destaca-se o papel da universidade na formação não somente por meio de disciplinas curriculares, mas também pelos eventos científico-culturais e pelos projetos de extensão com participação dos professores pesquisadores e alunos. Esses são espaçostempos de fruição e produção articuladas com a sala de aula para reflexão.

Pontua-se que esse campo é abrangente e, pela legislação atual, requer um novo olhar dos cursos, ampliando as disciplinas de prática para abranger a esfera artístico-cultural tão profícua, assim como outras áreas já são contempladas no currículo como a interpretação educacional, interpretação jurídica e da saúde.

Salienta-se que a tradução é experiência e é vivida, sentida e pensada por meio do encontro com a reflexão (BERMAN, 2007). A formação não pode prescindir de espaçostempos de fruição artístico-cultural para preparar profissionais capazes de atuar performaticamente nessa área.

\section{Referências}

AGENDA DE DANÇA. Dois Pontos Cia de DançaTeatro se apresenta pela primeira vez no Rio de Janeiro com dois eventos. 2018. Disponível em: http://www.agendadedanca.com.br/doispontos-cia-de-dancateatro-se-apresenta-pela-primeira-vez-no-rio-de-janeiro-com-dois- 
eventos/. Acesso em: 20 jan. 2020.

ANCINE (AGÊNCIA NACIONAL DO CINEMA). Instrução Normativa n.o 128, de 13 de setembro de 2016. Dispõe sobre as normas gerais e critérios básicos de acessibilidade visual e auditiva a serem observados nos segmentos de distribuição e exibição cinematográfica. Disponível em: https://www.ancine.gov.br/legislacao/instrucoes-normativas-consolidadas/instru-onormativa-n-128-de-13-de-setembro-de-2016. Acesso em: 20 jan. 2020.

ALBRES, N. A. Tradução intersemiótica de literatura infanto-juvenil: vivências em sala de aula. Cadernos de Tradução, Florianópolis, v. 35, n. 2, p. 387-426, out. 2015. https://doi.org/10.5007/2175-7968.2015v35nesp2p387.

ANJOS, R. P. dos. Cinema para LIBRAS: reflexões sobre a estética cinematográfica na tradução de filmes para surdos. 2017. 94 f. Dissertação (Mestrado em Estudos da Tradução). Universidade de Brasília, Brasília, 2017.

ASSIS SILVA, C. A. de. Cultura surda: agentes religiosos e a construção de uma identidade. São Paulo: Terceiro Nome, 2012.

BAKER, M.; SALDANHA, G. (eds). Routledge Encyclopedia of Translation Studies. London \& New York: Routledge, 1998.

BAKHTIN, M. Por uma metodologia das Ciências Humanas. In: BAKHTIN, M. Notas sobre literatura, cultura e ciências humanas. Tradução de Paulo Bezerra. São Paulo: Editora 34, 2017. p. 57-79.

BALANÇO GERAL FLORIANÓPOLIS. Palco Giratório. 2018. Disponível em: http://www.sesc.com.br/portal/site/PalcoGiratorio/2018/Edicao+2019/. Acesso em: 10 jun. 2020.

BASSNETT, S. Reflections on translating. Ontario: Multilingual Matters, 2011. https://doi.org/10.21832/9781847694102

BERMAN, A. A tradução e a Letra ou o Albergue do Longínquo. Rio de Janeiro: 7 Letras; PGET, [1985] 2007. (trad. de Marie-Hélène Catherine Torres, Mauri Furlan e Andréia Guerini).

BRASIL. Secretaria de Educação Fundamental. Parâmetros curriculares nacionais: arte/Secretaria de Educação Fundamental. - Brasília: MEC/SEF, 1997.

BRASIL. Lei no 10.098, de 19 de dezembro de 2000. Lei de Acessibilidade. Diário Oficial da União, Brasília, 20 dez. 2000. Seção 1 - Eletrônico - 20/12/2000, Página 2 (Publicação Original); Coleção de Leis do Brasil - 2000, Página 9010 2000a.

BRASIL. Lei no 10.048, de 8 de novembro de 2000. Dá prioridade de atendimento às pessoas que especifica. 2000b. Diário Oficial da União - Seção 1 - Eletrônico - 9/11/2000, Página 1 (Publicação Original); Coleção de Leis do Brasil - 2000, Página 7970 Vol. 2000b.

BRASIL. Decreto № 5.296, de 2 de dezembro de 2004. Regulamenta as Lei no 10.048, de 8 de novembro de 2000 , que dá prioridade de atendimento às pessoas que especifica. Diário Oficial da União - Seção 1 - 3/12/2004, Página 5 (Publicação Original).

BRASIL. Lei no 13.146, de 06 de julho de 2015. Institui a Lei Brasileira de Inclusão da Pessoa com Deficiência. Diário Oficial da União - Seção 1 - 7/7/2015, Página 12 (Veto).

BRASIL. Resolução no 7 MEC/CNE/CES, de 18 de dezembro de 2018. Estabelece as Diretrizes 
para a Extensão na Educação Superior Brasileira e regimenta o disposto na Meta 12.7 da Lei no 13.005/2014, que aprova o Plano Nacional de Educação - PNE 2014-2024 e dá outras providências. Diário Oficial da União - Seção 1 - 19/12/2018. Edição: 243, Página 49.

CALENDÁRIO FLORIPA. Mattinata - Canções Italianas em concerto com entrada gratuita em Florianópolis. Disponível em: http://calendariofloripa.com/board/77-1-0-9645. Acesso em: 10 jun. 2020.

CAMPOS, H. Da tradução como criação e como crítica. In: Metalinguagem e outras metas. 4. ed. São Paulo: Perspectiva, 2010. p. 31-48.

COKELY, D. Shifting positionality: a critical examination of the turning point in the relationship of interpreters and the deaf community. In: MARSCHARK, M.; PETERSON, R.; WINSTON, E. A. Sign language interpreting and interpreter education. Published to Oxford Scholarship. 2005. p. 03-28. https://doi.org/10.1093/acprof/9780195176940.003.0001

FESTIVAL. Festival de Folclore Surdo: o filme. 2016. Disponível em: https://vimeo.com/198998948. Acesso em: 10 jun. 2020.

FREIRE, P. Pedagogia do Oprimido. Rio de Janeiro: Paz e Terra, 1970.

FOMIN, C. F. R. Interpretação do português para libras no teatro: um olhar para a compreensão de espectadores surdos. Doutorado. Linguística Aplicada e Estudos da Linguagem. 2018. 250f. Dissertação. (Mestrado) - Pontifícia Universidade Católica de São Paulo, São Paulo, 2018.

JAKOBSON, Roman. Linguística e comunicação. São Paulo: Cultrix, 2005.

LARANJEIRA, Mário. Sentido e significância na tradução poética. Estudos Avançados, v. 26, n. 76, p. 29-37, 2012. https://doi.org/10.1590/\$0103-40142012000300005

LINDEN, Venicios Cassiano. A constituição da competência linguística no processo formativo dos alunos do bacharelado presencial Letras-Libras. 2014. TCC (Curso de Bacharelado em Letras-Libras) - Universidade Federal de Santa Catarina, Florianópolis, 2014.

NAPIER, J.; MCKEE, R.; GOSWELL, D. Sign Language Interpreting: theory \& practice in Australia and New Zealand. Sydney: The Federation Press, 2006.

NASCIMENTO, V.; NOGUEIRA, T. C. Tradução audiovisual e o direito à cultura: o caso da comunidade surda. Revista PERcursos Linguísticos, v. 9, n. 21, p. 105-132, 2019.

NOGUEIRA, T. C. Projeto tradcine: investigando a tradução para libras de obras cinematográficas. In: 6o CONGRESSO NACIONAL DE PESQUISAS EM TRADUÇÃO E INTERPRETAÇÃO DE LIBRAS E LÍNGUA PORTUGUESA. 2018. Anais ... Florianópolis, 2018. p. 120.

NSC TOTAL. Papo da Hora: agora tem peças de teatro em Libras e de graça em Florianópolis. Disponível em: https://www.nsctotal.com.br/noticias/papo-da-hora-agora-tem-pecas-deteatro-em-libras-e-de-graca-em-florianopolis. Acesso em: 20 abr. 2020.

RIGO, N. S. Interpretação em contextos artístico-culturais: um mapeamento de espaços acessíveis em Libras na cidade de Florianópolis/SC. In: XI CONGRESSO INTERNACIONAL DA ABRAPT E V CONGRESSO INTERNACIONAL DE TRADUTORES. 2013. Caderno de Resumos ... Universidade Federal de Santa Catarina - Florianópolis, de 23 a 26 de setembro de 2013. 
ROY, C.; METZGER, M. Researching signed language interpreting research through a sociolinguistic lens. The International Journal for Translation \&Interpreting Research, v. 6, n. 1, 2014. Western Sydney University. p.158-176. https://doi.org/10.12807/ti.106201.2014.a09

SAINT-EXUPÉRY, Antoine de. O pequeno príncipe. Dom Marcos Barbosa. Rio de Janeiro: Editora Agir, 2009.

SANTANA; J. B. M.; VIEIRA-MACHADO, L. M. da C. Formação de tradutores e intérpretes de português-libras na esfera artística e literária: projetos e reflexões teóricas. Translatio. Porto Alegre, n. 15, p. 238-263, 2018.

SANTOS, S. A. dos. Estudos da tradução e interpretação de línguas de sinais nos programas de pós-graduação em estudos da tradução. Revista da ANPOLL, v. 1, n. 44. p. 394-375, 2018. https://doi.org/10.18309/anp.v1i44.1148

SESC. 19a Mostra EmCenaCatarina Sesc circula por 12 cidades em outubro. 2019. Disponível em: https://www.sesc-sc.com.br/site/cultura/19-mostra-emcenacatarina-sesc-circula-por12-cidades-em-outubro. Acesso em: 14 jun. 2020.

SILVA NETO, V. S. da. A formação de tradutores de teatro para Libras: questões e propostas. 2017. 121 f. Dissertação (Mestrado) - Programa de Pós-graduação em Estudos da Tradução, Universidade de Brasília, Brasília, 2017.

STUDER, C. E.; CASAGRANDE, L. D. R. Aprendizagem significativa: relato de experiência no ensino superior. Paidéia (Ribeirão Preto), Ribeirão Preto, v. 9, n. 17, p. 61-68, 1999. https://doi.org/10.1590/S0103-863X1999000200007

SUTTON-SPENCE, R., FELICIO, M., MACHADO, A. F.; LEITE, T. de A., ANDRADE, L. L. de; BOLDO, B. J.; CARVALHO JUNIOR, D. Os craques da libras: a importância de um festival de folclore sinalizado. Revista Sinalizar, v.1, n.1, p. 78-92. 2016. https://doi.org/10.5216/rs.v1i1.35847

UDESC. Catálogo de extensão. Uma ponte entre a Universidade e a Sociedade. Disponível em: https://www.udesc.br/arquivos/udesc/id cpmenu/6861/Cat logo de Extens o 3156596 635726 6861.pdf. Acesso em: 21 jan. 2020.

UFES. Projeto de curso de bacharelado em Letras Libras. Vitória: UFES, 2013.

UFG. Projeto pedagógico do curso de letras: tradução e interpretação em libras/português (Bacharelado). Goiânia: UFG, 2014.

UFRJ. Projeto Pedagógico de Curso (PPC) Letras libras. Rio de Janeiro: UFRJ, 2013.

UFRR. Projeto político pedagógico do curso de letras/libras Bacharelado. Roraima: UFRR, 2014.

UFRGS. Projeto pedagógico do curso de bacharelado: habilitação tradução e interpretação de Libras (Libras-Português e Português-Libras). Porto Alegre: UFRGS, 2014.

UFSCAR. Projeto pedagógico do curso de bacharelado em tradução e interpretação em língua brasileira de sinais (libras)/língua portuguesa. São Carlos: UFSCAR, 2015.

UFSC. Projeto Político Pedagógico do Curso de Letras Libras - Licenciatura e Bacharelado - EAD. Florianópolis: UFSC, 2008.

UFSC. Projeto Político Pedagógico do Curso de Letras Libras - Licenciatura e Bacharelado Modalidade Presencial. Florianópolis: UFSC, 2009. 
UFSC. Projeto Político Pedagógico do Curso de Letras Libras - Licenciatura e Bacharelado Modalidade Presencial. Florianópolis: UFSC, 2012.

UFSC. Projeto do curso de Bacharelado em Letras, habilitação em Língua Brasileira de Sinais LIBRAS (EAD). Florianópolis: UFSC, 2019a.

UFSC. Regimento de Atividades Acadêmico-Científico-Culturais do Curso de Graduação em Letras-Libras - Bacharelado-, modalidade Presencial. 2019b.

Recebido em: 13/04/2020.

Aceito em: $12 / 10 / 2020$. 